\title{
Competency Development Management Geographic Teacher in Curriculum 2013 at SMA 1 Seyegan Sleman
}

\author{
Fajar Agung Nugroho \\ Graduate School \\ Universitas Negeri Yogyakarta \\ Yogyakarta, Indonesia \\ agung02nugroho@gmail.com
}

\author{
Hastuti \\ Graduate School \\ Universitas Negeri Yogyakarta \\ Yogyakarta, Indonesia \\ Hastuti@uny.ac.id
}

\begin{abstract}
This research aims to find out in terms of planning, organizing, implementing and directing, controlling and evaluating. This research is a qualitative descriptive method approach. The subject is the geography teacher. The data analysis technique used was using a model developed by Miles \& Huberman. The validity of the data using the Credibly Test, transferability test, dependability test and confirmability test. The results of the study 1) planning development of geography teacher competency formation of development team, analyzing teacher needs, preparation for implementation, preparation of material, determination of implementation time, preparing resource persons 2) organizing development of geography teacher competencies conducted the headmaster by giving orders to each team to be able to work together in order to succeed in developing teacher competency activities. 3) the implementation of the development of geography teacher competencies carried out was in the form of in-house Training activities, trainings and MGMP in Sleman district.
\end{abstract}

Keywords-Management, Curriculum, Geography

\section{INTRODUCTION}

Education is the right of every human being to live life. Without education, humans will not be able to have education, educational institutions are needed. In educational institutions there are various components, including the existence of a curriculum. On the other hand, education is one of the benchmarks for the progress of a nation. Law Number 20 of 2003 concerning the National Education System Article 1 paragraph 1 of education is "conscious and planned effort to realize the learning atmosphere and learning process so that students actively develop their selfpotential, personality, intelligence, noble character, and skills needed by themselves. , society, nation and state ". From this understanding it can be understood that education is one of the concrete forms as an effort to educate the nation's life as stated in the Preamble to Law Number 20 of 2003 concerning the National Education System article 3 which states that, "National education functions to develop abilities and shape character and dignified national civilization in order to educate the life of the nation.

The development of national education is an effort that aims to realize a quality, advanced, independent and modern Indonesian society. Educational development is an important part of a comprehensive and earnest effort to improve the dignity of the nation. Education is a future investment for a nation. The progress of a nation is very much determined by the quality of human resources and the quality of human resources is only very large for the progress of a nation, and a vehicle for building character and determining the human model that will be produced.

The education component that is very decisive for the implementation of the education process well is the teacher. Hamilton-Ekke [1] explains that teachers must be smart in choosing the right technique for learning, especially in order to achieve goals with maximum Education is the most important factor, because only through education can people optimize their talents and abilities. Education, human life is more violent because education is a process of change or a process of human maturation. For this reason, education is a very important need in advancing a nation's understanding. Indicators of a nation's progress are determined by the level of its human resources, and indicators of human resources are determined by the level of education. The better the level of education, the higher the human resources. The curriculum is a set of plans that contain lesson material that is used as a guide for the implementation of teaching and learning activities, has a very important position to realize educational goals that describe as abilities (knowledge and skills), values, and attitudes that must be mastered and possessed by students from an education unit. The curriculum provides the direction in which education and teaching are demonstrated. Thus, through the curriculum has a dynamic nature, it is supported by the question Mulyasa [2] which states that the curriculum is one component that has a dynamic nature means that the curriculum can be made changes and development so that it can adapt to the times

Planning and curriculum development must be based on general ideas about emerging curricula thanks to the interaction between theory and practice. The description of the problems of curriculum development has resulted in a diversity of opinions about various aspects of the curriculum field. Planning and curriculum development also involve enterprise human 
beings to define various effective learning opportunities. Therefore, Curriculum development involves many parties, especially teachers who work in class. Each teacher has an active responsibility in planning, implementing, evaluating, administering and changing curriculum. Basically, the teachers are the ones who know the various curriculum problems that have been implemented. The success of the curriculum is mostly in the hands of the teacher, as the curriculum implementer. The curriculum development process, there are many problems faced, which require its own consideration and solutions. All of these problems are caused by various conditions, which are adjusted to the guidelines and principles of needs that need to be met. Lack of leadership, planning and curriculum development can result in weak and less successful curriculum. Developers or parties involved in curriculum development activities should be aware of these problems, which can be categorized as general problems and special problems.

In connection with the educational process [3] explains that in fact the curriculum is the heart of an educational process with regard to physical and nonphysical elements. As we know that the 2013 curriculum at first only a few schools used it, SMAN 1 Seyegan is one of the schools that is given the authority to run the 2013 curriculum in Sleman Regency. Therefore, the school conducts a series of activities to implement the 2013 curriculum.

The enthusiasm of teachers and teaching staff of SMA Negeri 1 Seyegan in order to succeed in implementing the 2013 curriculum is reflected in the actions taken by internal schools and also preparing teachers and education personnel to conduct various training activities. The trainings related to the 2013 curriculum continue to be carried out by the Sleman District Education Office with the aim of being able to implement the 2013 curriculum well in each chool.

\section{LITERATURE REVIEW}

A study conducted by Khotim Hanifudin Najib entitled "Management of Professional Competency Development and Teacher Pedagogics for Implementing the 2013 Curriculum at Yogyakarta City Pilot Project High School" this study used a qualitative approach with the case study tradition. curriculum, teachers and heads of administration Data collection techniques by means of interviews, observation and documentation. Technical data analysis on Miles \& Huberman interactive model data analysis which includes data collection, data reduction, data presentation, and conclusion drawing. The equation of this research is development management related to planning, organizing, implementing, and directing, controlling and evaluating as well as on research approaches that use qualitative descriptive methods and types of case studies, the subject of his research was related to the principal, vice principal of the curriculum, teachers, and the head of administration, data collection techniques through interviews, observation, and documentation and technical data analysis referred to the Miles and Huberman model data, while the differences were in the place and time of the study, and point of view from the aspect of discussion. As well as the management of development on teacher competencies includes pedagogic, professional, personal and social competencies.

Another study conducted by Deitje Adoelfien Katuuk entitled "curriculum implementation management: Strategy for strengthening the 2013 curriculum implementation" This study uses a qualitative approach with case studies. Research subjects are teachers, principals, facilities, culture, environment. Data collection techniques through interviews, observation, and documentation. The equation of this research is management, approach with qualitative and subject of research teacher, principal. Data collection techniques use observation, interviews and documenting. The difference is at the level of education of junior high school, the point of view of the aspects of the discussion and different places and times.

\section{MATERIAL \& METHODOLOGY}

\section{A. Data}

Research data was collected by interviews from several teachers in high schools. An interview form is prepared by the researcher. Descriptive analysis method is used to analyze data. Information obtained from respondents through interview questions will be processed and will be explained by the researchers. Research respondents were high school 1 geography teachers, school principals, vice principals in the curriculum field, or school documents / archives. Sample selection technique is purposive sampling.

\section{B. Method}

This study uses qualitative research methods, which try to understand the facts from the perspective of the participants used in this study. This type of research refers to meaning, concept definition, characteristics, metaphor, symbol, descriptive of things and not on the number or size. Qualitative research approaches are used in many academic disciplines, especially in the curriculum. Research data was collected through observations, semi-structured interviews, and documentation.

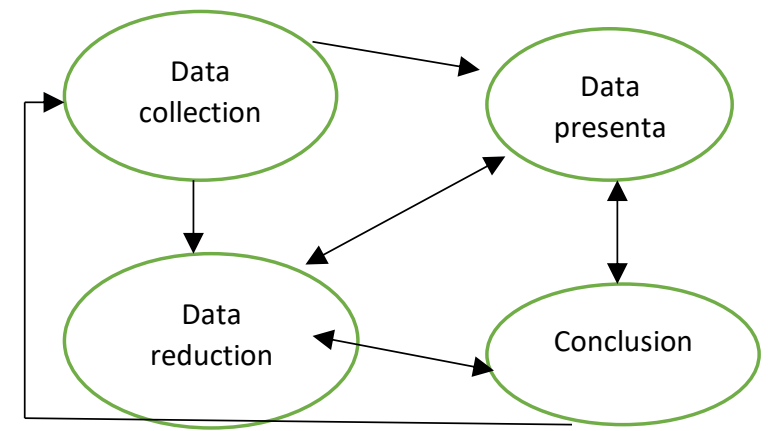

Figure 1. Data Analysis Model 


\section{RESULTS AND DISCUSSION}

\section{A. Result}

The form of teacher competency development activities in the 2013 curriculum has been implemented since the beginning of the 2013 curriculum applied in schools. Preparation of teacher competency development activities at Seyegan 1 Public High School is done carefully by the school. This is done because considering the competence of teachers is very influential on the smooth running of the 2013 curriculum 1 State High School at Seyegan. The form of teacher competency development conducted at SMA Negeri 1 Seyegan is in the form of attending educational seminars related to the 2013 curriculum.

1) In planning the development of geography teacher competencies in the 2013 curriculum at Seyegan 1 Public High School

Part of the initial activities that must be carried out in the organizational management process. A plan is generally in accordance with the objectives desired by an organization, while in this study the vision and mission of a High School 1 school is to form students who excel and are able to compete in various fields, forming high quality students in the fields of science and technology and art culture, Fostering a spirit of intensive independence to all school residents, Improving the skills of students in various skills oriented to future needs, Fostering appreciation for the teachings of the adopted religion so that it becomes a source of wisdom in acting, Strengthening the spirit of nationality and love of the homeland, Creating a school climate which supports learning. Based on the results of the study, teacher competency development activities in the 2013 curriculum at Seyegan 1 State High School began with forming a team implementing teacher competency development activities in the 2013 curriculum which would later be approved by the school principal. The development team consisted of principals, vice principals in the curriculum field, teachers, and administrative staff at Seyegan State High School 1. The team that has been formed will make a plan such as determining the development material, resource person, budget, and advice and infrastructure that supports the smooth running of the development activities.

2) Organizing the development of geography teacher competencies in the 2013 curriculum at Seyegan 1 Public High School.

Organizing the development of teacher competencies in the 2013 curriculum at SMA Negeri 1 Seyegan is in accordance with what was stated by Grifin in facilitating and facilitating a teacher competency development activity, the principal as chairman of the teacher competency development activity divides their respective tasks to team members implementing competency development activities teacher, so that in this behavior there was a delegation process of authority [2]. Furthermore, each team member has been given the task by the headmaster, who is obliged to arrange coordination between one another, especially coordination with the implementation chief or the principal.

3) Implementation and direction of developing geography teacher competencies in the 2013 curriculum

Participating in seminars, trainings, workshops, education and training is a real form of efforts to develop teacher competencies in the 2013 curriculum. Armstrong explains that "human resource development (HRD) is concerned with the providing of learning, development and training opportunities in order to improve individual, team and organizational performance, we can understand that the development of human resources will be related to providing learning opportunities and providing development and training in improving the performance of each individual, team and organization. The results of the study can be concluded that the results of the research with the theory are relevant, that all members of the team implementing the teacher competency development activities have carried out the tasks in accordance with the instructions of the head of the implementation or all members of the activity implementation team have carried out the tasks delegated by their principals.

4) Control and evaluation of the development of geography teacher competencies in the 2013 curriculum.

If a training activity and development activities are part of the process of knowledge renewal, skill renewal, and renewal of abilities possessed by a person or individual in order to improve performance, therefore training and development needs to be evaluated [10]. The results of the teacher competency research in the 2013 curriculum that have been carried out are in the form of teacher readiness in teaching, this is indicated by the existence of RPP, syllabus, learning media, and learning material. another thing is the use of the right learning time according to the scientific learning process. The form of supervision or evaluation carried out during the teacher competency development activities in the 2013 curriculum at Seyegan 1 Public High School is carried out by providing assistance and supervision in each of these development activities

Assistance here is carried out by a senior teacher or teacher who has been appointed by the principal or the head of the implementation of the teacher competency development activities. The task of the accompanying teacher here is to accompany the teacher who conducts the development activities so that the teacher accompanying the teacher who conducts the development after attending the teacher development activities in the 2013 curriculum. 


\section{B. Discussion}

The results revealed that in planning the development of four teacher competencies namely pedagogic, professional, social, and personality skills in the 2013 curriculum must be done carefully, meaning that it must be properly prepared until there is no mistake at all.

Organizing the development of four teacher competencies, namely pedagogical, professional, social, and personality skills in the 2013 curriculum must be properly distributed to all team members so as to minimize miss communication. The implementation of the development of four teacher competencies, namely pedagogical, professional, social, and personality skills in the 2013 curriculum is the core of the implementation of these activities. Therefore, this process is expected to work well. all members of the developer must work together well among other team members and can also communicate with the principal with the aim of achieving the objectives of an activity that has been carried out.

Control of the development of four pedagogic, professional, social, and personality in the 2013 curriculum is the final stage of the development activities. Control or survival that is carried out on the development program is expected to be a picture that is good for schools or related agencies

\section{CONCLUSION}

Based on the results of research on the management of geography teacher competency development in the 2013 curriculum in Seyegan State 1 High School, it can be concluded.

- From the planning of teacher competency development at SMA Negeri 1 Seyegan, it can be concluded a) analyzing the needs of geography teachers b) preparation for implementation c) preparation of geography material, d) timing of e) formation of a logging team.

- Organizing by the principal by giving orders to each team to work together.

- The implementation of the development here is in the form of a team of In-House Training (IHT) activities, trainings and following the MGMP in Sleman Regency.

- Supervision and evaluation carried out in the form of supervision carried out by the principal or senior teacher appointed to supervise.

\section{REFERENCES}

[1] Deitje Adoelfien Katuuk, Manajemen implementasi kurikulum: Strategi penguatan implementasi kurikulum 2013.Manado: Universitas Negeri Manado, 2014

[2] Griffin, R.W. Manajement. Boston:Houghton Mifflin Company, 1990

[3] Hamilton-Ekke, Conceptual framework of teacher'competence in relation to student' academic achhievement. Internasional Journal of Network and System, 2 (3), 2013, pp. 15-20.

[4] Hasan, S.H., Perkembangan kurikulum: perkembangan ideologis dan teoritik pedagogisMakalah disajikan dalam konferensi nasional sejarah, 2006, pp. 950-2005

[5] Khotim Hanifudin Najib. Manajemen Pengembangan Kompetensi Profesional dan Pedagogik Guru Untuk Implementasikan Kurikulum 2013 di SMA Negeri Pilot Project Yogyakarta. Yogyakarta: Universitas Negeri Yogyakarta, 2016.

[6] Mulyasa, H.E. Kurikulum Berbasis Kompetensi. Bnadung: Remadja Rosdikarya, 2003.

[8] -------. Guru Dalam Implementasi Kurikulum 2013. Bndung : Remaja Rosdakarya, 2015.

[9] Miles, M.B.\& Huberman, A M., Analisis Data Kualitatif , 2014.

[10] Naris, S.N \& Ukpere, W.I., Evaluation of human resource development and training at a higher educational institution in namibia. African journal of business management, Vol.6, 2012, pp. $11859-11864$

[11] Undang-undang Nomor 20 Tahun 2003 tentang Sistem Pendidikan Nasional Pasal 1 ayat 1 . 